\title{
The WWW Cabinet of Curiosities: A Serendipitous Research Tool
}

\author{
Josie Arnold ${ }^{1}$ \\ ${ }^{1}$ School of Social Sciences, Swinburne University of Technology, Lilydale, Australia \\ Correspondence: Josie Arnold, School of Social Sciences, Swinburne University of Technology, Locked Bag 218 \\ Lilydale, Victoria, 3140, Australia. Tel: 61-392-157-147. E-mail: jarnold@swin.edu.au
}

Received: July 18, 2012

Accepted: August 28, 2012

Online Published: October 15, 2012

doi:10.5539/jel.v1n2p238

URL: http://dx.doi.org/10.5539/jel.v1n2p238

\begin{abstract}
This paper proposes that the WWW is able to be fruitfully understood as a research tool when we utilise the metaphor of the cabinet of curiosities, the wunderkammer. It unpeels some of the research attributes of the metaphor as it reveals the multiplicity of connectivity on the web that provides serendipitous interactions between unexpected materials thus bringing new ways of thinking about a given research topic.It explores how the singular research journeys may express themselves so differently that they find a comfortable space for a definition only within an academic cabinet of curiosities. Yet these differences are also made available through utilising an academic search engine in the WWW because it doesn't literally obey the instruction you have given it. I give examples of methodologies and theories that I have found to be apposite for such serendipity. I show that the narrative of the research journey is a significant contribution to knowledge through explicating a subjective academic narrative in an auto-ethnographic methodological framework.
\end{abstract}

Keywords: metaphor and research, auto-ethnography, serendipity of WWW

\section{Introduction}

Much is obvious about the value of the WWW as a research tool. The object of this paper is to look at the serendipitous nature of this as I have discovered it by writing a subjective academic narrative as the methodological framework. This paper thus both describes and utilises this qualitative methodology that I call a subjective academic narrative. It participates in the privileged scholarly discourse about methodology in the knowledge domain.

Since the middle of the $20^{\text {th }}$ century, with paradigmatic certainties challenged and all but banished by feminism and postmodernism, academics have turned more and more towards qualitative methodologies both in themselves, or as adding to quantitative data. In many ways the old battle lines between patriarchal, scientific, enlightenment models of knowing and more uncertain, personal and even feminist ways of knowing have been smudged. The disorderly and even disruptive discourse of poetics and the personal has begun to be valued in the academy alongside the orderly and in many ways complacent discourse of scientific methodology. In valuing the self as data, dynamism is added to academic debate. The Enlightenment period of Western thinking replaced Christian theological ways of knowing with scientific methodologies. Such modes have, of course, been spectacularly successful for Euro American ways of knowing (Todorov 2009). They have become normative. So they are the measure against which all other cultures and their ways of being and knowing are measured (Tanner 1996).This paper practises the ways in which late $20^{\text {th }}$ and early $21^{\text {st }}$ century critical and cultural thinking has challenged this and hence added new and dynamic possibilities to ways of knowing within the academy.

Within the academy there remains a space in which we can develop new ways of publishing our work that provide narratives peculiar to the person writing the works that are accepted as both academic and subjective. This opens up the privileged academic discourse to display itself within an auto-ethnographic framework that explores the individuality provided by the postmodernist dispersal of certainties.

Ethnographers have increasingly come to realise that their studies inevitably involved themselves (Anderson 2006: 375) and from this realization a relatively new academic discipline has evolved under the aegis of Carolyn Ellis and Arthur Bochner. (2001). They have emphasized the role of the subjective academic self within the study undertaken and reported upon. Ellis has called this personal performative experience "evocative or emotional".

Auto-ethnography involves "explicit and reflexive self-examination" (Anderson 2006: 375) that may be also termed, according to Leon Anderson "biographically opportunistic research", the "self-narrative", or 
"confessional tales" about the individual scholar's experiences of their field work. This brings together the autobiographical and the ethnographic in research into social worlds. Anderson claims that "the term auto-ethnography has become almost exclusively identified with those advocating the descriptive literary approach of evocative ethnography" (2006: 377) and, although he argues against it, it is this aspect of the methodology that most interests me.

This accords with the views of Ellis and Bochner that: "the mode of story-telling is akin to the novel or biography and thus fractures the boundaries that normally separate social science from literature" (2000: 744). Anderson notes that "evocative ethnographers...remain largely marginalized in mainstream social science venues, due to their rejection of traditional science values and styles of writing" (2006: 377).

This auto-ethnographic challenge to genre within academic discourse is also an outcome of the postmodernist moment in the acceptance of variability in knowledge structures, methodologies and theories rather than the urge for replication and certainty. Offering multiple possibilities, postmodernist theories arose in the mid $20^{\text {th }}$ century for a number of reasons concerned with thinking differently from the Enlightenment and cultural "givens" that had led to scientific reasoning dominating other forms of thought. (Riger 1992) They also acted as a reaction against the certainties of fascism. The revelations of the Holocaust after World War 2 had shocked the Western World. Critics of cultural and social constructions began to compare society to a textual discourse. Literary theorists were already questioning the authority of the text. They had indicated the author had no control over the construction of the text once it was written. The author became the writer. (Barthes: 1977) The writer was no longer an authority figure: s/he worked with the reader to bring the text to life. Indeed, it was emphasised that unless the reader took up the text it was forever inert.

This emphasis upon the role of the reader as a co-writer of the text has taken the authority of the academy into other and more challenging areas of knowledge production. In discussing the WWW as a serendipitous research tool, I utilize the metaphor of the wunderkammer or cabinet of curiosities. In doing so I challenge traditional modes of academic expression so as to open them to poeisis. This opposes the prosification of the world post-Enlightenment and participates in imaginative and discursive methods of world disclosure (Cascardi \& Middlebrook 2012). I have thus written in a subjective non-conformist academic methodology that is based on personal insights rather than theories and evidences.

\section{The Cabinet of Curiosities}

The cabinet of curiosities, also called the wunderkammer (Westerhoff 2001), was a space for the entertainment of gentlemen of taste and education, especially those English gentlemen who had as young men taken the Grand Tour of Europe. It consisted of a cabinet that very often looked ordinary on the outside, but had a heavily decorated interior full of drawers and sections. In these were placed curiosities that had no singular connective link beyond that they aroused interest in the beholders and, if fortunate indeed, those who were permitted to handle the contents. The entertainment consisted of several elements. Primarily it showed the wealth of the owner who had travelled and/or bought up these interesting contents. Then it displayed that the collector was a man of taste who could provide after-dinner discussions that showed how knowledgeable he was and how, by inference, his guests were also men of informed vision and exquisite if eclectic taste. It was also a space that called for discussion and debate about the objects, allowing a certain gravitas of intellect to be the focus of the after-dinner entertainment rather than gossip, cards or other less educative or more speculative activities.

Such cabinets of curiosities are still available for purchase today, and they prefigure the urge to collect objects of interest and participate in the urge to collect objets d'art that may be more focussed and singular. 


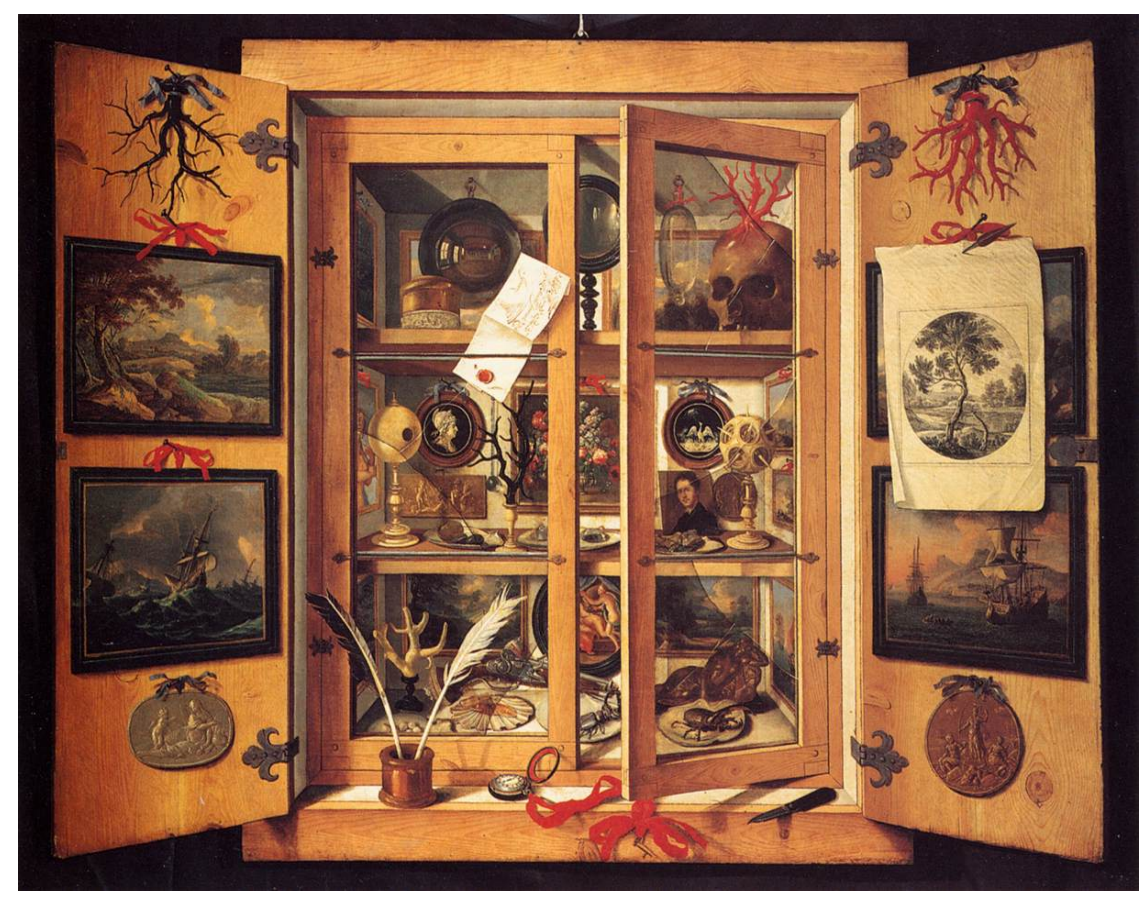

Figure 1. A traditional wunderkammer

Collecting various materials is a very human trait that has become a central aspect of modern museums and the personal and institutional commerce in objects. In some cases, it can be seen as obsessive and even manic behaviour. Whilst not the purpose of this paper to explore this urge, it should be recognised as a central aspect of data collection and interpretation within the academy. This following photograph of a colleague's collection of media-related materials is an indicator of such a collection.

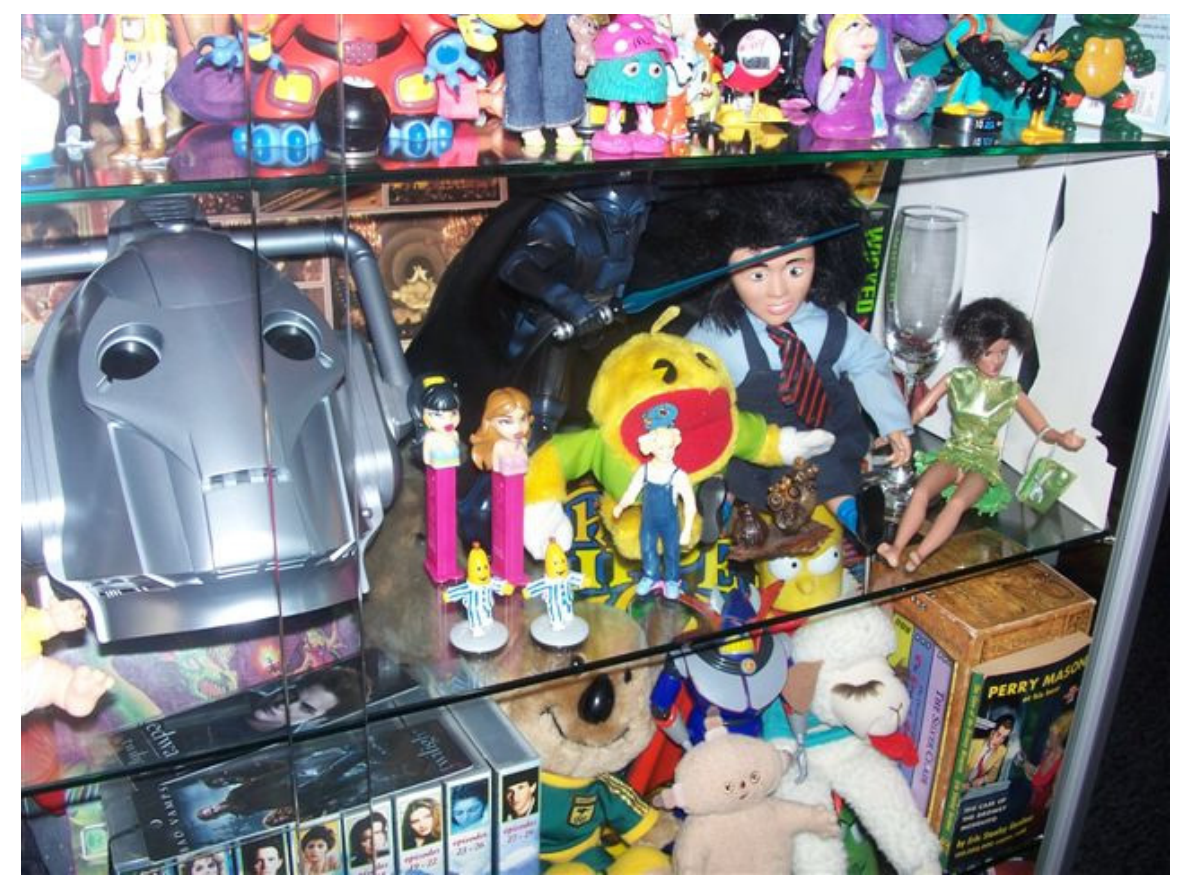

Figure 2. A media colleague's wunderkammer 
This paper asserts that research is serendipitously extended and enabled by the WWW and that this has interesting implications for researching and researchers. These include chaotic methodologies, serendipitous connections, challenges to linearity, the opening up of academic discourse and accepting the WWW as a place of liminal entry space.

There is still an apparently unbreachable division between serious "hard data" and less acceptable "soft data". Silvia Gherardi and Barry Turner discuss qualitative and quantitative data collection in the provocative terms incorporated in their booklet title: "Real men don't collect soft data". They see that in the social sciences "hard" is masculine and to be respected whilst "soft" is feminine and of a lower order of activity. They explain that while the soft data is unreliable and too personal, even the hard data must be shown to be collected by academic methods that are acceptable, detached, institutionalised and "with a reduced willingness to tolerate ambiguity in proceedings and findings" (1987: 5). Moreover, they note that this is enacted through editorial practices in refereed journals. This has changed little since their study. See, for example, directions from this and other journals to would be authors.

The wunderkammer challenges such focus. This is not because it is stuffed full of easily recognised associated materials: a cabinet that may more easily be kept under lock and key than displayed for its diversity and the possibilities that such diversity might lead us to as read and handle the contents and then, perhaps, yawn. Gherardi and Turner stifle that yawn as they assert that research in all areas is "more messy, more convoluted and more surprising than we thought it would be" (2007: 7). This acceptance of a certain chaos echoes the words of Kathryn Hayles who states that "chaos is the womb of life, not its tomb" (1991: 100). The Enlightenment model that underpins our contemporary western ways of knowing, and is still largely the measure against which other ways of knowing are judged, is the very human attempt to overcome chaos by imposing order. It is a cabinet full of only one replicated and replicable type of academic methodology. What if this changes and chaos is embraced? "New discoveries become available for us if we can step out of the harnesses of orderly models and methods" (Strand 2005: 504).

\section{Chaotic Methodologies and Theories}

Metaphor enables us to bring together disparate ideas so as to form a richer understanding. According to Gherardi and Turner, such use of the metaphor in research has "complex, pervasive connotative symbolic qualities" that reach far beyond using them "solely as an information processing device...virtually all language and thought is metaphoric" (1987: 19). Today, there exist many qualitative methodologies that challenge academic Enlightenment models of knowledge.Today, there does exist a space that embraces what Gherardi and Turner see as a "middle ground" between the traditional scientific academic methodologies (the hard) and the more exploratory ones (the soft) even within the qualitative domain (2007: 7). Following the wunderkammer metaphor, however, those methodologiesand theories that I briefly yet in some wonder wish to explore in this paper all describe a variety of approaches under collective terms. The methodologies are: practice led/based, auto-ethnography and the baroque. The theories are: post-colonialism, feminism and queer. I propose that these are all facilitated by the lateral and serendipitous nature of the WWW as a source for academic discourse and literature. They are all "chaotic" methodologies and theories that I would like to bring out of my cabinet of curiosities and/as I googled the WWW.

\section{Practice Led/Based Research}

$\mathrm{PL} / \mathrm{BR}$ is a challenge to traditional research practices and paradigms. It acts to bridge the gap between theory and practice by bringing postmodernist theories of textuality and discourse to life as academic practice. It shows clearly that there is a dynamic relationships between theory and practice through recognising as academic knowledge the practicum as well as the analytical. In doing so it acts to bridge the Cartesian mind/body split and also acts to galvanise what could become moribund practices of traditional critical analyses models arising from the natural sciences research model standing alone as academic insights into practice. As practitioners develop and explain their own practices by undertaking research based upon further insights and extensions of knowledge about their own practices they place them firmly within the academy. Much is known about data collected from external sources for the production of knowledge. However, the interior life of the academic as a researcher collecting/producing data is less open for both scrutiny and as a complementary way to knowledge production within the academy.

Rather than being described (or more usually proscribed) as diminishing or weakening the academy, there are many opportunities offered the academy through seeing PL/BR as an alternative pathway into academic knowledge and credentials. By enabling an understanding that research can follow rather than critique practice or 
act in a different knowledge domain from the academic, PL/BR opens up the academy to new methodologies and theories that enact dynamic relationships between theory and practice.

Enabling practitioners to develop further insights and extensions of knowledge about their own practices and to place them within the academy acts to galvanise what could become moribund practices of traditional critical analyses models arising from the natural sciences predominant standing as academic insights into practice. Drawing upon those aspects of university research that are not within the Natural Sciences model to broaden concepts of knowledge and gate-keeping across a wider range of research areas and practicesincreases an academic understanding that research can follow practice rather than act in a different knowledge domain.

By bringing together the Cartesian mind/body binary, PL/BR also presents opportunities for practitioner researchers from demographics that are not readily recognised by university models of knowledge to credential cultural knowledge practices such as narrativity or cultural status/awareness and knowledge. PL/BR is a pathway by which practitioners may enter the academy. It is also a challenge to the academy to accept "uncredentialled" practice as being an entry-point for practitioners who may not have qualifications that are familiar to the gate-keeping and regulatory functions that are a necessary function of the academy.PL/BR provides a deepening and broadening of concepts of knowledge that acts to enrich the range of activities developed within the academic structures of the university.

Philosopher Mary Midgely Is concerned with addressing and redressing the powerful influence of the Cartesian binary of cogito ergo sum: I think therefore I am. She contends that: “....all reasoning is powered by feeling and all serious feeling has some reasoning as its skeleton. Thought and feeling are not opponents, any more than shape and size". (2004: 9). In her discussion of the underpinning of academic knowledge structures by such Enlightenment thinking, Midgely sees traditional research based on the natural sciences as one of the myths that we live by that produce "... patterns of thought that are really useful in one age [that] can make serious trouble in the next one" (2004: 4). Her discussion leads us to examine critically from various perspectives the ways in which research paradigms proclaim a certain acceptable way of thinking, acting, publishing and teaching within the academy even as critical eyes are turned against such norms. These are powerful influences. For example a common editorial instruction in refereed journals eschews the mere personal narrativity as a non-method, instructing that submissions should not be subjective.

This paper, too, is concerned with how and why traditional research constructs proclaim themselves as logical and reasonable within a given framework (usually based on the natural sciences and Enlightenment thinking) and then establish, de facto, that framework as the "norm" by which all other research is judged.There exists still an interesting and challenging debate about what is seen/understood to be knowledge within the academy (Barron; Bourke \& Neilson 1996; Candy et al. 2007). Illuminating and articulating practice as knowledge is a challenge in an academic environment that has not always seen practice as knowledge and often still struggles to do so (Maarit 2007).The creative practitioner brings to the academy new dimensions of what knowledge itself consists of, and how this contributes to learning. Because this disputes the regular academic templates, it challenges the academy itself (Harper 2008).

\section{Auto-ethnography}

In her claim for the validity of auto-ethnography as a research methodology, Tai Peseta rejects the criticism of personal academic narrative as a "narcissistic dump". She asserts that "the ways a research community stories its narratives of usefulness tells us about the hegemonies and orthodoxies of a field". She enjoins researchers to think about "odd" or "unruly" methodologies and extend knowledge about "what constitutes useful knowledge and research..." (2007: 19). She recognises that her own research journey has been dominated by a binary between her personal feelings and research that involved domination by "outcomes, effectiveness, and impact" (2007: 20). I write extensively about this as "the subjective academic narrative".

This research story is an example of the auto-ethnographic as it is concerned with myself as datainvestigating how the wunderkammer of the WWW produces serendipitous connections that are singular. The auto-ethnographist arose from the ethnographic when the researchers of other racial groups discovered that they were themselves deeply involved in a story. Arthur Bochner says that "I want a story that moves me, my heart and belly as well as head; I want a story that doesn't just refer to subjective life, but instead acts it out in ways that show me what life feels like now and what I can mean" (2002: 270). This is obviously facilitated by a personal journey through the wunderkammer of the WWW research materials.

Although life stories make up our academic work as well as other aspects of our lives, they are not restrained to the purely personal and subjective: they enable us to tell our own stories, but also to reflect upon the telling of those stories and to add to new and significant knowledge within the academy in this broader methodological 
and theoretical sense. (Plummer 2005). Elsewhere I have described this as "the subjective academic narrative" (Arnold 2010). Ken Plummer uses this as a challenge: "it brings with it the possibility for such enquiry to engage in poetry and poetics, drama and performance, philosophy and photography, video and film, narrative and stories" (2005: 363).

There has been a considerable growth of understanding of the postmodernist position that qualitative methodologies based upon singular experiences contribute in a scholarly way to knowledge itself. For example, Sarah Wall states that: "auto-ethnography is an emerging qualitative research method that allows the author to write in a highly personalised style, drawing on his or her experience to extend understanding...the intent of auto-ethnography is to acknowledge the inextricable link between the personal and the cultural and to make room for non-traditional forms of enquiry and expression" (2006: 146). Writing about my own experiences and the insights that they offer, then, becomes a qualitative methodology that resides readily within the auto-ethnographic frame. Nicholas Holt sees this as "...a genre of writing and research that connects the personal to the cultural, placing the elf within a social context." (2003: 18). For him, an academic article is a "writing story" that challenges traditional academic claims of verification and disinterestedness.

\section{Baroque Methodology}

The term Baroque is now used by academics to describe how singular personal research journeys may express themselves so differently that they find a comfortable space for a definition only within an academic cabinet of curiosities. Yet these differences are also made available through utilising an academic search engine in the WWW because it doesn't literally obey the instruction you have given it.

The possibilities offered by the serendipitous nature of the unstructured WWW entries found for me by google scholar are described by Dixi Strand as matching her own "abandonment of disciplinary boundaries working in the muddled area of information technology design, use and management from a plethora of perspectives" (2005: 500). She reports that “...the Internet's success grew out of horizontal networking practices, incrementally and without any master plan..." (2005: 501). She identifies traditional research practices as, unlike the baroque, becoming directive maps that demand conformity from researchers.

The baroque methodology can be clearly seen in the serendipitous nature of WWW search that throws up unexpected connections through its search engine which is outside the direct control of the researcher. According to Maggie MacLure's definition, "a baroque method would resist clarity, mastery and the singular point of view, be radically uncertain about scale, boundaries and coherence, and favour movement and tension over structure and composure" (2006: 729). This means giving up mastery over our research, not posing a direct and in many ways defining and enclosing question, and being led to where the material takes us. At the same time, when we open the wunderkammer we are placing an area of research under our scholarly eye and we do make choices about what we take from that cabinet and what we ignore or reject. It is the baroque that allows us to make that scholarly journey by accepting the unusual, the unexpected, even the undesired, and utilising it to take our research forward to what makes a satisfactory position- if not conclusion -for us as scholars. It does participate in the scholarly conversation even as it disrupts its certainties and allows new dynamics and finer nuances to enter the academic domain.

In accordance with Deleuze and Guattari's (2004) dismissal of the tree of knowledge and their embracing the rhizomatic uncontained image of growth, baroque methodology entails "our ability to resist control, or our submission to it..." (Deleuze 1995: p 176). Such an ability leads to what I have called the chaos of the theory-contents of the cabinet of curiosities made available on the WWW. The baroque is never definitive in whatever material or research sense it makes itself known: it is always singular and hence it is able to cope with contradictions as it recognises that submission to rules or orderly discourse cannot describe the richness of a disorderly and unruly world within dominant research models. The result of baroque methodology is to disrupt the expectations involved in researching in given modes. In this way "reason" paradoxically is shown to be unattainable "unreason". Handling the unconnected items in the cabinet of curiosities is interesting not only because there is an unexpected and provocative juxtaposition, but also because the act of wonderment is involved.

The baroque not only accepts difference and complexity: it utilises it to lead to new and unexpected connections and ideas that recognise complexity as well as wonder at it. Western knowledge is based upon the classical linearity of order reinforced by Enlightenment methodologies that have been extraordinarily productive and have lead to great advances in the human condition as well as in academic knowledge. The baroque methodology is not some mischievous fancy to undo that: instead it offers another way to think about and do research. The baroque is different from rather than better than; it seeks complexity rather than resolution. 


\section{Post-colonialism}

Post-colonialism involves the struggle for re-invention by the once colonised countries that yearn to return to an impossible past that they recognise as no longer attainable. Thus post-colonialism uncovers the ways in which dominant cultural practices out of the western tradition have changed if not traduced both players; the colonised and the coloniser.As the victors/colonisers write the history, the construction of the subordinate becomes the established historical perspective (Spivak 1999; 2002). Thus, GaytariSpivak shows, when we read the written perspectives on the Anglo-Indian Wars of the $18^{\text {th }}$ century, we read fromthe perspective of the invader. She quotes a Major General D. Ochterlony writing in 1784: "The aggression of the Goorkahs compelled us to have recourse to arms in vindication of our insulted honour". His words are instructive: for him, it is the Ghurkhas who are at fault. They are aggressive. This aggression compels a response that is somehow innocent of aggression itself. The English take up arms only to vindicate their honour that has been insulted by the opposition to them. Yet they are on Ghurkha/Indian territory! Spivak sees this as a construction of the past that is influential in the present as it has established a way of thinking about colonisation and the colonised that is still pervasive.

Of English as an Imperial task even today, Spivak says that: "It is sadly evident that, in the global village the same system of (linguistic) exchange must operate; it must complete the work of imperialism" (1999: 369). It is clear in her search for a postcolonial identity that social and cultural systems are contingent and political, not universal.This postmodernist moment that claims to be open to all cultural difference is itself intrinsically European. It is embedded in the European text from which it arises and in which it is expressed. For Spivak in her search for postcolonial identity and the right for the subordinate native to speak and be known rather than being the oppressed unknown native companion, "It is impossible for contemporary French intellectuals to imagine the kind of Power and Desire that would inhabit the unnamed subject of the Other of Europe" (Spivak 2000: 265).

Nevertheless, the materials that come from the Western "contemporary French intellectuals" and others who oppose the dominance of cultural metanarratives are as essential to post-colonialism as they are to any deconstructive practices: that is, very necessary indeed. The fracturing of "givens" can be very fruitfully applied outside the dominant Western culture. In this context of both applying and contesting the postmodernist dispersal of paradigms, we can re-engage with the once silenced subordinate "native" from non-Western cultures. This subordinate, Spivak's "un-named native informant", has already suffered geographic colonisation and subsequent de-colonisation. In what ways can we think about enabling this doubly silenced voice?

This perspective emphasises that traditional Western scientific, logical and hence linear ways of attaining insights, knowledge and even wisdom are rather more spurious than conventional wisdom would have them be. This is because they implicate thinkers in the act of putting together ideas as a painstaking construction that attempts to construct an unreachable yet highly desirable "reality". Spivak gives as another example how the archives of the British Raj constructed a simulacrum of Imperial India that is still proposed today in European films. She cites the movies "Out of Africa" and "Gandhi" (2000: 202) as having grown from those colonial records of what it was then to be an Indian. Importantly this is in the minds of the colonisers, and from their records. In reaching a global audience, these cinematic reconstructions contain convincing portraits that become the accepted truth that is in fact yet another Western cultural metanarrative. Spivak reads the records of the British commercial powers in India with dismay and disbelief, at the same time finding in them reasons for the postcolonial struggle for self-understanding: "The records I read showed the soldiers and administrators of The East India Company constructing the object of representations that becomes a reality of India" (2000: 203). For her, as for all contemporary post-colonial Indians, this is not the India they know and want known.

It is a poignant realisation for Spivak that the postcolonial narrative is as constructed as the pre-colonial idyll and the colonial oppression. However, she notes that the archives of the Raj have a dominant narrative of the colonial period that imbues a false story even in postcolonial times. Academics and researchers as well as nationalists and politicians see archives as a true representation of the realities of the colonial times tat form and inform the postcolonial search for identity. They are described all to often as being historically accurate. They are authoritative in time and historical acceptance, and are seen in what Spivak terms as an impossibility. This is "...the willed autobiography of the West (that) masquerades as disinterested history..." (Spivak. 2000: 208). Although the British Raj is no longer physically or politically present, it influences the postcolonial representations and search for identity. Note an Indian journalist, Amrit Dhillon, writing recently in the Melbourne Australia Age newspaper (2012: 11) reveals that Indian women so yearn to be white that they are buying bleaching materials to make white vaginas for their husband's delectation: white is the object of desire! Dhillon says that "what is so repugnant about this product is that it is guilty of a double self-hatred-of race and 
gender".

Such sexism does not only apply to India. In the same week, the conservative populist paper the Herald Sun in the same city runs a front page shocker banner headline: "War on Sexism. Fight Back. World-first study says time to take a stand" (van den Berg. 2012: 1).

Whilst we might agree that, especially from a feminist reading, disinterested history is an impossibility, yet there remains a postcolonial battle occurring about who owns what history. A similar case to that cited by Spivak regarding India occurred in 2006 in Australia where the conservative Government began what has been popularly termed "the history wars". This is a battle about who owns the past that has a significant impact upon the present. In these "history wars", conservative anglo-celtic majorities claim that a "black arm band view of history" is promulgated by a large group of Marxist historians who have an agenda of maximising the indignities suffered by the Indigenes and minimising the heroic virtues of the colonisers. In doing so, they ascribe a subordinate position to the Indigenes both past and present.

This "history war" continues to debase the Indigenous subordinate and silence the native informant. For example, in their open letter to the Prime Minister in 2006, Donald Gumurdal, Philip Mikinjmikginj, and Jacob Nayinggul, traditional owners of Kuniwinjku country in Arnhem Land gently but firmly castigate him for his lack of knowledge and presumptuous assumptions. They are responding to his Government's assertions that “...spending months on ceremony doesn't work in today's culture”. For them, such an assertion "... is wrong. Our ceremony is part of our work. That's why we call it "business". In our country, in Arnhem Land, ceremony has continued uninterrupted for a very long time. It is important to our culture, our art and our moral beliefs....It takes a lot of organisation...Everyone has to work for ceremony business. Young kids are initiated to learn the hard rules; we don't want them to stop. Trouble comes when you lose the culture...." It is inevitable that colonisation has led to the loss of culture. What is not inevitable, and what I think Spivak struggles with in her postcolonial questions about the subordination and silencing of the once-colonised still occurring, is that multiple cultures could NOT be valued as one another. To do so, one must first be aware that the history battle is not an innocent attempt to establish a "truth". "If the project of Imperialism is violently to put together the episteme that will "mean" (for others) and "know" (for the self) the colonial subject as history's nearly-selved other, the example of these deletions indicate explicitly what is always implicit: that meaning/knowledge intersects power." (Spivak 2002: 215).

\section{Feminism}

This is also evident in black feminism in America. There an anthropological view exists that Irma McClauren claims has developed a "backdrop of historical social and scholarly malignment and academic racism" (2001: 1). She discusses this as "institutionalised racism" in North America as faulty alignment leading to a marginalisation that is ever-present in the academy which has developed a scholarship that reinforces societal inequalities. She describes "black feminism" as working against eurocentrism/ethnocentrism as it is "produced as much out of silence as out of the testimonials, autobiographies, novels, poetry, music and songs of the black women who are our foremothers..." (2001: 10).

Feminism is a very broad umbrella term for many different ways of acting against dominant patriarchal norms. These various feminisms have brought new epistemological standpoints to the academy, showing the gendered nature of acceptable academic knowledge processes and content, and challenging the academy's closed paradigms. This highlights the political nature of the exercise of power within the patriarchy and its unwillingness to share. Multiple feminisms are often contradictory, but they share this unwillingness to be dominated by patriarchal givens and a readiness to look for the welfare of women.It is generally agreed that feminism is a theory of highlighting the subordination of women within a culture and society that is overtly and covertly dominated by the patriarchy. It enables us to see the social interactions from perspectives that are not the dominant academic or cultural "givens". The value in this is apparent, but for me it is most valuable in preventing stasis in the privileged academic discourse as well as highlighting the subordination of women in the culture. The many feminist theories have, in academe, provided new ways of thinking, knowing and seeing and it is this that I emphasise and celebrate here. Other feminisms celebrate a greater transgression against cultural metanarratives: they provide a very radical perspective of liberation that overthrows power structures as an act of freedom-fighting so as to "refigure what it means to be female in relation to what it means to be male" (Showden 2012: 13).

Camilla Gibb, in her prize winning novel "Sweetness in the belly" gives us another view of women in a repressive patriarchal system. A 5 year old girl, Rahile, wants an Absuma, a girl's party, and so it is arranged. Why is it to be attended by the midwife? Too soon, we know: 
"The midwife lifted up her skirt and spread her plump, dimpled legs. She pulled up Rahile's dress as well and tied the girl's thighs to the soft insides of her own with two long black scarves. Then she put a cloth in Rahile's mouth, told her to bite hard, tugged at the folds of skin between Rahile's legs and swiftly ran a metal blade down over them...the midwife made several quick slices with the blade, removing thin bits of skin. All the colour drained from Rahile's face. A tremor rippled through her body as a thick pool of blood grew between her legs...the blood began to creep over the side of the bench. Rahile caught sight of it as it lurched toward the ground and she let out an agonized cry...then the midwife tugged the scarves loose and scooped the girl up under the arms. Nouria grabbed the deadened heap of her daughter, and the two women lay her down on the bench. The midwife pinched together the two remaining flaps of skin between Rahile's legs and began piercing them perfunctorily with a row of six sharp thorns...The midwife inserted a matchstick between the last two thorns... and held her over a small smouldering pit of aromatic wood so that the smoke washed up over the wound. She held out her callused hand, and Nouria passed her warm ashes from the fire, which she patted up and down between the thorns with her flat fingers...the midwife wrapped a bandage round and round her legs, binding her immobile from her hips to her feet." (2005: 75-6).

Regarding the woman who wears the burqa, the Afghanistan writer Khaled Hossein in "A thousand splendid suns" gives us a novelist's view of the imagined lived experience of her character that emulates her own lived knowledge:

"When they went out together, he walked alongside her, one hand gripping her elbow. For Laila, being out in the streets had become an exercise in avoiding injury. Her eyes were still adjusting to the limited, gridlike visibility of the burqa, her feet still stumbling over the hem. She walked in perpetual fear of tripping and falling, of breaking an ankle stepping into a pothole." (Hossein 2007: 208). When we read such fictional events that reveal a truth, third wave feminism seems to reveal a pallid view of women's lives seen through a particular distorting prism.

In investigating the proposal that third wave feminism is a revolt against being one's mother's sister, Astrid Henry explores "matrophobia". She says that "In fact, it appears that for many younger feminists, it is only by refusing to identify themselves with earlier versions of feminism- and frequently with older feminists- that they are able to create a feminism of their own." (2004: 7). Many third wave feminists, particularly African-Americans assert that second wave feminism “... has become overly elitist and academic...it is out of touch and unreal for young women." (2004: 154). Furthermore, they see earlier waves of feminism as non-generational in a familial sense. Rather it is another tidal force that provides them with an inheritance that they themselves must shape. They are "no longer 'victim feminists', but privileged daughters of the second wave." (2004: 156).

This third wave of feminists no longer seeks to be "politically correct". Young feminists from the privileged "euroamerican" background see themselves as singular and thus grouped only through complexity. There are voices raised against this from within the site of privilege such as Kay Hymowitz's provocative article entitled "Why feminism is AWOL on Islam." After a terrifying litany of reported and identifiable offences against women and girls, she fiercely states that feminists "...have averted their eyes from the harsh, blatant oppression of millions of women, even while they have continued to stare into the Western patriarchal abyss, indignant over female executives who cannot join an exclusive golf club and college women who do not have their own lacrosse teams." (2003: 2).

She answers the question in her title by a statement that contemporary feminism is now "...mired in self-righteous sentimentalism, multicultural nonjudgementalism, and international utopianism" that it can no longer take the moral high ground on anything. Indeed, “...feminism has lost the language to make the universalist moral claims of equal dignity and individual freedom that once rendered it so compelling" (2003: 3). It is clear that Hymowitz has her own axes to grind, but that does not mean that she is not inadvertently bringing something very important to the fore. Bray, discussing Helene Cixous, says: "to argue that we have now escaped the clutches of an oppressive past, that somehow we are more democratic and more enlightened simply because time has passed, is to retain a rather naïve faith in a linear narrative of historical progress. New limitations of what it means to be a sexed being are now facing new subjects, while some of the older limitations are still very much in place." (2004: 5).

Largely euroamerican, third wave feminism is locked into the past through its matrophobia and into the present through its white/middle-class orientation of individuality and singularity. When those locked out from its privileged position form their own wave, it will be a tsunami. How will proponents of third wave feminism deal with this? 


\section{Queer Theory}

Feminism differs from queer theory in that it recognises sexual dominance in the "norms" of the patriarchy and acts against them, whereas queer theory accepts no such definitions (Showden 2012: 21). Queer Theory arose from gay and lesbian studies where those on the periphery of the culture because of their sexual choices and orientations asserted their right to be heard in a way that ensured the academy received multiple perspectives on materials studied and opinions and ideas put forward within privileged academic debates. This attitude of non-conformity was apparent in the hetero-normalisation that underpinned many studies within the social sciences and the humanities as well as being the basis of academic knowledge models.

Because the queer were outside the "norms" they introduced new and quite radical ways of thinking about normalcy that transcended gender differences and assumptions. So the very word "queer" carries a signification far beyond its sign: "a word that was commonly understood to mean "strange", "odd", "unusual", or "sick" and was routinely applied to lesbians and gay men as a term of abuse, now intimates possibilities so complex and rarified that entire volumes are devoted to spelling them out" (Halperin 2003: 339). What this offers all researchers is the ability to think differently: to read against the givens so as to produce richer and more insightful discussions. It is this ability to be disruptive rather than contented that leads to new thinking and acting and that makes queer theory so attractive to provocative academic discourse.

What would the academy be like if everything was unsettled and different: if everything was queer and there was no barrier of the social norms? For David Halperin the institutionalized acceptance of these propositions about queer theory are paradoxical: he is concerned with the delimitation of gay and lesbian theory, for example. What I concentrate upon here, however, is the very fact that queer theory has been accepted within then academy and hence has contributed to radicalised thinking beyond accepting or utilising social norms. Halperan's passionate cry is basic to my thinking when he calls upon the academy to see such a theory as not a reformulation of postmodernist critical positions from the boundaries but as "quite concretely, reinventing its capacity to startle, to surprise, to help us think what has not yet been thought" (2003: 343). For me this is not a way of normalising nor ignoring gay and lesbian studies, but rather a way of seeing what they have brought to the academy from the border position.

Certainly it provides a valuable and quite practical tool for the self-reflexive researcher. Such self-reflexivity is increasing as the society becomes more e-literate and the world changes so rapidly for those who are e-connected (Plummer 2005: 358). Because this is dominated by euroamericans and the global language of English, this by its present nature locks out many others, so any view from the periphery that enriches academic knowledge is to be ultra appreciated. For Plummer: "Queer theory puts everything out of joint, out of order" so that it not only questioning gender appellations and distinctions from past "givens" but also "is a messy, anarchic affair...it transgresses and subverts" (Plummer 2005: 360). Plummer draws our attention to the paradox of having any cohesive or able-to-be-defined theory that claims to be against such definitions and norms, deciding that "ambivalence is the name of the game" for researchers espousing such qualitative research methodologies.

Rather than only being seen as a contradiction and defiance of traditional methodologies, for me queer theory opens up possibilities related not only to gender and sexuality but also to "a refusal for all orthodox methods-a certain disloyalty to conventional disciplinary methods" (Plummer 366). This is chaos unbridled and may lead to many new perspectives and ways of reading and writing the culture, but at its base is always the revelation of the author's self in ways that lead to assumptions being revealed and challenged through such critical self-awareness.

Gay and lesbian identities are constructed by culture and society, and queer theory made this visible through its questioning of the fixed nature of such identities (Eves 2004: 480). Concerned originally primarily with matters of sexuality and identity, this theory has been changed to take into account the strangeness of the norm rather than the need to fight for difference. Many gay and lesbian theorists think that this means the theory has been hijacked and the strength of the revolutionary thinking has been dispersed and hence weakened rather than broadened and hence strengthened. Some feminists also consider that it has weakened radical feminist views of sexuality (Showden 2012).

\section{Serendipitous Connections in the WWW}

As "the world is rarely standardised in itself" Gherardi and Turner (1987: 11), connections that are not immediately evident or do not become apparent in research may be found by using the WWW through such search engines as Google Scholar that facilitate discovery rather than verification. Gherardi and Turner describe discovery research as a kind of research in which order is not very immediately attained, a messy, puzzling and intriguing kind of research in which the conclusions are not known before the investigations are carried out 
(1987: 12). This is a good a description of opening up the wunderkammer, the cabinet of curiosities, and examining its disparate contents to see what can come of this viewing, not to make a replicable generalisation.

When we enter a research area into a search engine, it does the work for us of opening up the wunderkammer and giving us displays that we had not conceived of in making the entry. Lennart Bjorneborn and Peter Ingwersen discuss how "due to its dynamic and distributed nature, the Web often demonstrates web pages simultaneously linking to each other- a case not possible in the traditional paper-based citation world" (2001: 66) This "dynamic and distributed nature" of the WWW provides us with unexpected collections of refereed journal articles that would be suitable for the flexibility and unindexable nature of the cabinet of curiosities. They note too that their own country of Norway "was much more visible on a web scale than in the printed world" (2001: 68), and indicate their concern about what to trust as reliable information placed on the web. Bjorneborn and Ingwersen account for my astonishment with these 2001 stats: "the web can be conceived as an exponentially growing distributed data base, containing now in its indexable part well over one billion pages and well over 10 billion links" (72). I utilise google scholar and ebsco host through my University library, and can see that the articles are from reliable journals that have a policy of peer review. What astonishes me is the variety of hits that I get from my search for a specific area, and I am comparing this to opening the wunderkammer, for I have read materials that I would once never have found relevant and interesting to my research topic because there was no link to them in the inexorable classifications of traditional research libraries.

My preferred search engine google scholar explains itself thus:

What is Google Scholar? Google Scholar provides a simple way to broadly search for scholarly literature. From one place, you can search across many disciplines and sources: articles, theses, books, abstracts and court opinions, from academic publishers, professional societies, online repositories, universities and other web sites. Google Scholar helps you find relevant work across the world of scholarly research.

\section{Features of Google Scholar}

- Search diverse sources from one convenient place

- Find articles, theses, books, abstracts or court opinions

- Locate the complete document through your library or on the web

- Learn about key scholarly literature in any area of research

How are documents ranked? Google Scholar aims to rank documents the way researchers do, weighing the full text of each document, where it was published, who it was written by, as well as how often and how recently it has been cited in other scholarly literature.

Its index depends upon the words that are in the initial topic search line, and a "topic distillation" of such words appear in various ways in multiple areas of published scholarly studies and these "links weave documents together in a complex, structured hypertext corpus" (Bjorneborn and Ingwersen 2001: 72). The building of "transversal links" by scholars who choose unexpected materials is described by Bjorneborn and Ingwersen as "boundary crossings" that depend upon "human serendipity" and "could render useful information" and "creative insights" that develop "evolving interconnectedness" leading to new knowledge (Bjorneborn and Ingwersen 2001: 75). Debra Slone's study of internet users shows that "whether experienced or not, they relied on serendipity..." (2002: 1152). Bjorneborn calls this "web mining" that is exploration of the Web conducted in convergent (i.e., rational, goal-directed) ways complemented by divergent (i.e., intuitive, serendipitous) behaviour (2001: 2).

\section{Challenges to Linearity via the WWW}

In a challenge to linearity of research methods based largely upon number counting and crunching, Gherardi and Turner state provocatively that "as the rules of a painting by numbers kit relate to artistic creation, so do sets of research procedures relate to successful scientific investigation" (1987: 9). They go on to show how numbers are a mathematical metaphor not a reality statement despite the "peculiar standing of numbers in our civilization" (1987: 10). What has become as significant and peculiar to western research is the WWW and the search engines that interrogate it.

Such challenges to the linearity that other methods of entering into research debate offer include the need for researchers to "review and question the ontological and epistemological assumptions which form the basis of their knowledge" (Gherardi and Turner 1987: 20). This paper participates in that review and questioning. 


\section{The Opening up of Academic Discourse Because of the WWW}

Inherent to searching the WWW for academic discourse that entices us into its discussionsis a readiness to give up our preconceptions and yearning for certainties, and to embrace difference. Such academic discourse is based on what Gherardi and Turner term "a series of interactions with the social world in a form which plausibly alerts us to the possibility of a new order not previously seen-a theoretical account" (1987: 14). Also basic to academic discourse is the review of the relevant germinal and current literature on the topic under discussion. This involves academics in welcoming the wide and deep reading of current as well as germinal refereed journal articles and scholarly works as a part of their research. I believe that it is imperative that academic work is clearly shown to be a participant in current academic thinking and discourse.

The only way for this to happen is for researchers to situate themselves within the privileged academic discourse. David Boote and Penny Beile (2005: 3) state that "a thorough, sophisticated literature review is the foundation and inspiration for substantial, useful research." An insightful privileged academic discussion (once and sometimes still called the literature review), also means that researcher-practitioners see the reading, understanding, utilising and critiquing points made in the literature as an "engine" that drives their own work forward.

\section{Conclusion: Accepting the WWW as a Place of Liminal Entry Space}

There is much that has been said and much that can be said about the value of the WWW as a research tool: that, however, is not the privileged academic discourse into which I am entering in this paper. Rather I am looking at the poeisis of how the WWW can be viewed as a serendipitous space for discovery of data that would otherwise be unread and/or not connected up. In this sense, the WWW provides aliminal space that is the entry point into the unknown. It is a site of uncertainty and discovery. It metaphorically describes how, in the hallway of our research, we are open to many possibilities even as we enter into a given area of discourse. It is well explained in religious discourse, as religion looks at holy spaces outside the everyday that are the threshold of the unattainable presence, and utilises allusive ritual as more than bonding: it also enters into the elusive mysteries themselves. It is the place of engagement between the god/s and women and men; it is the space between the things of this world and the other/next (Arnold 2010). In the research context that I am exploring in this paper, the WWW is a liminal space that provides endless possibilities for information gathering. This is particularly so for refereed journal articles and scholarly materials when we use an engine such as google scholar. In The Name of the Rose, Umberto Eco builds a mystery around knowledge held within an extensive and secret series of libraries that can only be entered into by the initiated. This metaphor of a library is one that enables our understanding of the WWW by bringing its immensity into a size and style that we can apprehend.

For the academic, this liminal space can be troubling. Traditionally we are attuned to walking through it to define a destination. Approaching the entry point to the wunderkammer, however, we may have only the slightest knowledge of the area that we are interested in investigating by opening up possibilities and handling that which we did not know could be there. Making the liminal the space of approaching, of open-ness, of an entry point to itself is not congruent with scholarship that seeks to reveal and to solve. Moreover, when we utilise the self as data, we are making this space even more open to itself rather than to another more defined room. This may lead us to a more fractured and less focussed method of approaching our research that challenges the perspectivity of eurowestern thinking. Are we ready to open and handle the multiple possibilities offered by the cabinet of curiosities held in the WWW?

It is in the liminal space exemplified by the WWW as a research tool that we can approach both a given topic and ways of knowing that are far from given. I have used 2 metaphors for this space, because it takes our thinking and research activities from the linear and direct into possibilities that, while unexpected, often offer a richness of dialogue and discussion that we would never have achieved through traditional research methods. Perhaps the wunderkammer is always displayed in the hallway?

\section{References}

Arnold, J. (2007). Practice Led Research: A dynamic way to knowledge. The Rock View Press. Melbourne. Australia.

Arnold, J. (2010). The liminal and apophatic voice of the writer in/as autobiography: a subjective academic narrative. Text, $1(1)$.

Arnold, J. (2005). The PhD in Creative Writing Accompanied by an Exegesis. Journal of University Teaching and Learning Practice, 2(1), 36-50. Retrieved from http://jutlp.uow.edu.au/

Arnold, J. (2007). Practice Led Research: A dynamic way to knowledge. Melb. Aust. The Rock View Press. 
Barron, D., \& Zeegers, M. (2012). 'O'for Osmosis, 'P' for Pedagogy: Fixing the postgraduate wheel of fortune. Retrieved from http://www.aare.edu.au/02pap/bar02605.htm (May 22, 2012).

Bjorneborn, L. (2001). Small world linkages and co-linkages. $12^{\text {th }}$ ACM Conference on Hypertext and Hypermedia.

Bjorneborn, L., \& Ingwersen, P. (2001). Perspectives of webometrics. Scientometrics, 50(1), 65-82. http://dx.doi.org/10.1023/A:1005642218907

Bochner, A. (2000). Criteria against ourselves. Qualitative Enquiry, 6(2), 266-272. http://dx.doi.org/10.1177/107780040000600209

Boote, D. N., \& Beile, P. (2005). Scholars Before Researchers: On the centrality of the dissertation literature review in research preparation. Educational Researcher, 34(6), 3-15.

Bourke, N., \& Neilson, P. (1996). The problem of the exegesis in creative writing higher degrees. TEXT, Special Issue(3). http://www.griffith.edu.au/school/art/text/speciss/issue3/bourke.htm

Candy, L., Amitani, S., \& Bilda, Z. (2007). Practice-led strategies for interactive art research. CoDesign, 1(1), 209-223.

Cascardi, A., \& Middlebrook, L. (2012). Poiesis and modernity in the old and new worlds. Vanderbilt University Press.

Deleuze, G. (1995). Negotiations .N.Y. Columbia University Press.

Deleuze, G., \& Guattari, F. (2004). Anti-Oedipus: capitalism and schizophrenia. London. Athlone Press.

Dhillon, A. (2012). The Indian obsession with fairer skin sinks to a new low. The Age. Melb.

Eves, A. (2004). Queer theory, butch/femme identities and lesbian space. Sexualities, 7(4), 480-496. http://dx.doi.org/10.1177/1363460704047064

Gherardi, S., \& Turner, B. (1987). Real Men Don't Collect Soft Data Quaderno 13. Dipartmento di Politica Sociale Universita di Trento.

Gibb, C. (2005). Sweetness in the belly. Canada. Anchor.

Gumurdal, D., Mikinjmikginj, P., \& Nayinggul, J. (2006). Sit with us Mr Howard. We will help you understand. The Age (pp.11). Melbourne. Australia.

Halperin, D. (2003). The normalization of queer theory. Journal of Homosexuality, 45(2), 339-343. http://dx.doi.org/10.1300/J082v45n02_17

Harper, G. (2008). Creative writing: words as practice-led research. Journal of Visual Art Practice, 7(2), 161-171. http://dx.doi.org/10.1386/jvap.7.2.161_1

Hayles, K. (1991). Chaos Bound: Orderly disorder in contemporary literature and science. Cornell University Press.

Henry, A. (2004). Not my mother's sister: generational conflict and third wave feminism. Ithaca. N.Y. Indiana University Press. Retrieved from http://www.swin.eblib.com.au.ezproxy.lib.swin.edu.au/EBLWeb/patron/ebook.Ithaca. N.Y

Holt, N. (2003). Representation, Legitimation, and Autoethnography: An Autoethnographic Writing Story. International Journal of Qualitative Methods, 2(1), 18-28.

Hossein, K. (2007). A thousand splendid suns. London. Bloomsbury.

Hymowitz, K. (2003). Why feminism is AWOL on Islam. City Journal, 13(1). Retrieved from http://wwwcity-journal.org/html/13_1_why_feminism.html.

Maarit, M. (2007). Knowing through making: The role of the artefact in practice-led research. Knowledge, Technology \& Policy, 20(3), 157-163. http://dx.doi.org/10.1007/s12130-007-9028-2

McClauren, C. (2011). Black Feminist Anthropology. Theory, Politics, Praxis and Poetics. New Brunswick. Rutgers University Press.

Midgely, M. (2004). The myths we live by. Oxon and New York. Routledge.

Peseta, T. (2007). Troubling our desires for research and writing within the academic development project. International Journal for Academic Development, $12(1), \quad$ 15-23. http://dx.doi.org/10.1080/13601440701217253 
Plummer, K. (2005). Critical humanism and queer theory. In Denzin, N., \& Lincoln, Y. (Eds), The Sage Handbook of Qualitative Research (3rd ed, pp. 357-373).Thousand Oaks, CA: Sage Publications.

Riger, S. (1992). Epistemological debates, feminist voices. Science, values and the study of women. American Psychologist, 47(6), 30-740. http://dx.doi.org/10.1037/0003-066X.47.6.730

Showden, C. (2012). Theorising maybe: A feminist/queer theory convergence. Feminist Theory, 13(3).

Slone, D. (2002). The influence of mental models and goals on search patterns during web interaction. Journal of the American Society for Information Science \& Technology, 53(13), 1152-1169. http://dx.doi.org/10.1002/asi.10141

Spivak, G. (2002). A Critique of Postcolonial Reason.Cambridge. Mass: Harvard University Press.

Strand, D. (2005). Let's be baroque. European Journal of Information Systems, 14, 500-503. http://dx.doi.org/10.1057/palgrave.ejis.3000558

Tanner, R. (1996). The passion of the Western mind: understanding the ideas that have shaped our world. U.S.A. Crown.

Todorov, T. (2009). In defence of the Enlightenment. London. Atlantic Books.

Van den berg, L., \& Fight Back (Unknown). The Herald Sun (pp.1 \& 8). Melbourne.

Wall, S. (2006). An Autoethnography on Learning About Autoethnography. International Journal of Qualitative Methods, 5(2), 146-160.

Westerhoff, J. (2001). A world of signs: baroque pansemiotism, the polyhistorical and the early modern Wunderkammer. Journal of the History of Ideas, 62(4), 633-650. http://dx.doi.org/10.1353/jhi.2001.0041 